\title{
Reducing the Spread of Covid-19 by Buying Healthy Vegetarian Food at Home \\ (Aplikasi Vege! Mengurangi Penyebaran Covid-19 Dengan Membeli Makanan Sehat Vegetarian Dirumah)
}

\author{
Andhika \\ Universitas Universal, Indonesia \\ E-mail: andhika@uvers.ac.id
}

\begin{abstract}
Abstrak
Abstrak - Covid19 adalah virus mematikan yang telah mengakibatkan perekonomian masyarakat dunia menjadi hancur. Banyak negara berlomba-lomba untuk menutup negara nya dari pendatang-pendatang yang diduga sebagai penyebar virus. Seluruh toko baik itu restoran ataupun penjual makanan pokok dijalanan berhenti melakukan penjualan. Penjual takut akan penularan virus yang disebabkan oleh sentuhan ataupun jarak antar manusia yang terlalu dekat. Penyebaran melalui uang kertas disinyalir menjadi faktor tertinggi dalam penularan penyakit. Oleh sebab itu kami mengembangkan metode pembayaran kedalam aplikasi tanpa menyentuh uang kertas. Penjual tetap merasa aman menjual makanan dimana pun berada karena pembayaran bisa dilakukan secara digital didalam aplikasi vege. Dengan begitu masyarakat tetap akan merasa tenang walaupun sedang menerapkan isolasi mandiri dirumah selama pandemi. Aplikasi yang dirancang menggunakan android diharapkan dapat mengjangkau sebagian besar masyarakat yang lebih mempunyai ponsel android dari pada ponsel yang lain. Aplikasi vege adalah aplikasi penjualan makanan vegetarian yang berkapasitas rendah dan dapat dipasang oleh sebagian besar versi android walaupun itu ponsel jadul sekalian. Pembeli tidak perlu dating ke restoran ataupun ketempat penjual makanan untuk membeli makanan. Pembeli hanya perlu memesan dan membayar melalui aplikasi untuk pembelian makanan vegetarian. Dengan cara ini diharapkan mampu mengurangi penyebaran virus covid 19 melalui uang kertas.
\end{abstract}

Kata kunci: Mobile Programming, Vegetarian, Kesehatan, Covid 19, Android

\begin{abstract}
Abstract - Covid19 is a deadly virus that has been destroyed by the people of the world to be destroyed. Many countries are competing to close their countries from migrants who turn to spread the virus. All shops, whether restaurants or staple food vendors, stop selling. The seller is afraid of the transmission of the virus caused by touch or distance between humans that are too close. Spread through banknotes was allegedly the highest factor in disease transmission. Therefore we developed a payment method into the application without involving banknotes. The seller is still safe selling food everywhere, because payments can be made digitally in the vege application. Thus the community will remain calm while it is working on independent isolation at home during the pandemic. Applications that are designed using Android are expected to be able to reach most people who have an Android phone from other phones. The vege application is a vegetarian food sales application that is low capacity and can be installed by most versions of Android even though old school phones are all. Buyers do not need to come to a restaurant or place to buy food to buy food. Buyers only need to order and pay through the application for vegetarian food purchases. In this way it is expected to reduce the spread of covid 19 virus through banknotes.
\end{abstract}

Keywords: Mobile Programming, Vegetarian, Health, Covid19, Android

\section{Pendahuluan}

Wabah besar dan terus meningkat dari sebuah novel coronavirus dilaporkan di Wuhan, provinsi Hubei China [1], [2], yang dapat menyebabkan penyakit pernapasan akut dan bahkan sindrom gangguan pernapasan akut fatal (ARDS) [3]. Coronavirus baru telah dikonfirmasi penularan dari manusia ke manusia [4], [5], dan karena untuk transportasi besar-besaran dan mobilitas penduduk yang besar. Dengan penyebaran SARS-CoV-2 yang sangat cepat itu maka dinyatakan sebagai Emergency Kesehatan Masyarakat Internasional Kepedulian (PHEIC) oleh WHO pada 30 Januari 2020 [6], dan penilaian tingkat global dari risiko penyebaran dan risiko dampak COVID-19 telah meningkat menjadi sangat tinggi oleh 
WHO pada 28 Februari 2020 [7] yang merupakan ancaman besar bagi WHO bagi kesehatan masyarakat internasional. Dengan penyebaran virus yang sangat cepat itu salah satu nya dikarenakan oleh sentuhan tangan saat memegang uang untuk membayar makanan setiap hari. Pada saat memegang uang yang sama dari penderita bisa menyebar kan virus secara cepat tanpa disadari. Uang adalah hal yang sangat berpotensi tinggi dalam penyebaran COVID-19. Dalam perkembangan teknologi android saat ini, harus nya penyebaran virus ini dapat dicegah. Dengan ponsel pintar android yang sekarang menjadi alat komunikasi wajib bagi setiap orang bisa dimanfaatkan untuk bertransaksi pengganti uang dalam pemesanan makanan. Banyak organisasi berusaha memahami cara memanfaatkan kombinasi unik konten, data, dan fungsionalitas yang disediakan oleh perangkat seluler [8]. Mobile perdagangan adalah platform di mana pengguna dapat membeli produk menggunakan perangkat seluler yang terhubung melalui data nirkabel koneksi [9] [10]. Dengan adanya masalah global covid-19 yang cepat menyebar diberbagai negara, aplikasi android bisa menjadi solusi dalam mengurangi penyebaran virus tanpa harus keluar rumah untuk membeli makanan dan minuman sehat vegetarian dimana diluar rumah masyarakat sangat tinggi berpeluang untuk tertular covid-19. Dengan berdiam diri dirumah saat pandemi covid 19 juga membantu memutus penyebaran covid-19. Masyarakat bisa memenuhi kebutuhan pokok seperti makanan dengan sangat mudah di aplikasi android serta bisa membayar dengan uang digital seperti transfer uang digital. Ini akan menjadi solusi untuk tidak menyebarkan covid-19 dengan uang kertas dimana uang kertas banyak disentuh oleh orang-orang yang belum tentu pasti negatife covid-19.

Agar penelitian terarah dan sesuai dengan tujuan yang diharapkan, maka diberikan batasan khusus pada masalah motode pembelian makanan vegetarian menggunakan aplikasi android tanpa harus menggunakan uang kertas. Yang seperti itu langkah pemecahan masalah tidak terlalu terdistorsi dari penelitian yang dilakukan. Sehingga tujuan yang diharapkan dapat tercapai. Dari permasalahan ini, penulis memiliki tujuan memberikan solusi pencegahan penyebaran covid 19 melalui uang kertas saat pembelian makanan vegetarian dengan menggunakan aplikasi vege. Makalah ini disusun sebagai berikut, Bagian pertama kami menggambarkan Potensi Penyebaran Covid-19, Komputasi Seluler, Kebutuhan Belanja dalam lingkungan seluler, Sistem Operasi Android, dan Perkembangannya. Dalam Bagian kedua kami menjelaskan Metodologi, perangkat keras, dan perangkat lunak yang digunakan untuk pengembangan pembelian makanan vegetarian menggunakan ponsel android. Bagian ketiga tentang ini penelitian adalah Hasil dari pengembangan aplikasi Android sebagai salah satu solusi untuk mengurangi penyebaran virus covid-19. Bagian keempat adalah bagian dari Kesimpulan dan Pekerjaan masa depan.

\section{Potensi Penyebaran Covid-19, Komputasi Seluler \& Kebutuhan Belanja Pokok}

Epidemi penyakit coronavirus-2019 (COVID-19) menetapkan darurat medis yang menjadi perhatian dunia dengan bahaya penyebaran yang sangat tinggi dan mempengaruhi seluruh dunia. Di India, telah terjadi peningkatan tajam pada infeksi dengan 20.080 kasus pada 21 April bahkan setelah penutupan di seluruh negeri. Model penguncian \& penahanan Bhilwara meratakan kurva infeksi COVID-19 hanya dalam waktu 10 hari dari penyebaran awal. Makalah ini telah menggambarkan model Bhilwara dan membandingkan model dengan India COVID-19 lockdown bersama dengan prediksi untuk pengurangan jumlah kasus yang akan datang dengan implementasinya. Dalam eksperimen, model Bhilwara disimulasikan menggunakan teknik pemasangan kurva polinomial derajat ke-3, dan laju pertumbuhan rata-rata infeksi dihitung pada kurva spread COVID-19 selama beberapa hari yang menggambarkan pengaruh kebijakan yang ditetapkan oleh administrasi Bhilwara. Dengan menggunakan laju pertumbuhan rata-rata yang dihitung, COVID-19 spread diperkirakan dengan regresi polinomial derajat ke-3 dengan menggunakan dataset dari semua negara bagian India. Hasil menemukan bahwa dengan penerapan model Bhilwara di seluruh India, tingkat penularan infeksi berkurang ke tingkat yang signifikan. Hasil memotivasi otoritas pemerintah untuk menerapkan kebijakan baru dan adaptasi model penahanan Bhilwara untuk meratakan kurva wabah COVID19 [11]. 
Thomas Quatieri "A Framework for Biomarkers of COVID-19 Based on Coordination of SpeechProduction Subsystems"

Sasaran: Kami mengusulkan pemodelan pidato dan kerangka kerja pemrosesan sinyal untuk mendeteksi dan melacak COVID-19 melalui tahapan asimptomatik dan simptomatik. Metode: Pendekatan ini didasarkan pada kompleksitas koordinasi neuromotor di seluruh subsistem bicara yang terlibat dalam respirasi, fonasi dan artikulasi, dimotivasi oleh sifat COVID-19 yang berbeda yang melibatkan lebih rendah (yaitu, tabung bronkus, diafragma, trakea bawah) dibandingkan atas (yaitu, laring), radang saluran pernapasan faring, oral, dan hidung [1], serta oleh semakin banyak bukti manifestasi neurologis virus [2] - [5]. Hasil pendahuluan: Sebuah studi eksplorasi dengan wawancara audio dari lima subjek memberikan ukuran efek Cohen antara pra-COVID-19 (pra-paparan) dari pasca-COVID-19 (setelah diagnosis positif tetapi tanpa gejala) menggunakan: koordinasi pernapasan (diukur melalui amplitudo bentuk gelombang akustik) dan gerakan laring (frekuensi dasar dan puncak puncak cepstral), dan koordinasi gerak laring dan artikulasi (frekuensi pusat forman). Kesimpulan: Meskipun ada ketergantungan subjek yang kuat, morfologi tingkat efek ukuran kelompok menunjukkan pengurangan kompleksitas koordinasi subsistem. Diperlukan validasi dengan dataset yang lebih besar dan terkontrol dan untuk mengatasi pengaruh yang membingungkan seperti kondisi perekaman yang berbeda, jumlah data yang tidak seimbang, dan perubahan dalam status vokal yang mendasari dari rekaman waktu sebelum-ke-pasca [12].

Yiru Wang, Ran Xu “COVID-19 and Retail Grocery Management: Insights from a Broad-based Consumer Survey"

Sebagai salah satu dari beberapa sektor ritel yang beroperasi, industri ritel makanan menghadapi tantangan dan peluang unik selama Novel Coronavirus 2019. Pandemi menyebabkan berbagai transformasi dalam industri ritel makanan, termasuk perubahan dalam persepsi dan perilaku konsumen. Meskipun pandemi memiliki sifat situasional, transformasi tersebut dapat memiliki efek sementara dan jangka panjang pada reformasi industri ritel bahan makanan. Kami memeriksa konsumen yang mengubah perilaku belanja bahan makanan selama pandemi menggunakan survei di antara 2.500 orang dewasa A.S. Hasil survei menunjukkan bahwa konsumen sekarang memiliki harapan yang lebih tinggi untuk keselamatan di dalam toko; mereka telah mengurangi frekuensi perlindungan toko, waktu perjalanan, dan durasi di dalam toko; mereka telah mengubah jadwal belanja dan tujuan belanja; dan mereka telah menghabiskan lebih banyak per perjalanan belanja. Peningkatan pembelanjaan di dalam toko juga sejalan dengan peningkatan transaksi di berbagai platform belanja bahan makanan online, yang menciptakan persaingan sempurna dalam industri ritel bahan makanan online yang muncul. Persaingan sempurna seperti itu adalah unik dalam dunia e-commerce monopoli secara keseluruhan dan menciptakan peluang baru bagi platform untuk mereformasi dan mengembangkan bersama industri ritel bahan makanan online yang berkelanjutan. Kami selanjutnya memunculkan implikasi manajerial dalam jangka pendek dan jangka panjang untuk toko-toko batu bata dan mortir serta penjual grosir online [13].

\section{Komputasi Seluler}

Kombinasi teknologi seluler dan sosial online jaringan mengarah ke dunia yang sangat menarik bagi pengiklan seluler dan lebih umum bagi penyedia layanan seluler. Intinya, sebagian besar layanan yang tersedia melalui desktop akan segera diakses terutama melalui sejumlah besar perangkat seluler [14]. Dan ini akan sangat berpengaruh kepada pergerakan ekonomi masyarakat. Perkembangan yang sangat cepat mengakibatkan kemudahan bagi sebagian masyarakat. 


\section{Kebutuhan Belanja Makanan Pokok}

Proses belanja makanan pokok lazimnya mencakup kegiatan-kegiatan seperti sebelum berbelanja, disaat belanja, dan setelah belanja. Kami mendefinisikan kegiatan berikut: Sebelum belanja, berarti konsumen berpikir untuk membeli sesuatu. Disaat belanja, pengeluaran yang berkelanjutan menentukan tahap dimana konsumen memasuki toko dan mulai berpikir apakah akan memutuskan untuk membeli barang atau tidak. Setelah belanja termasuk pembayaran dan logistik setelah memilih barang. Juga, layanan purna jual harus dipertimbangkan [15].

\section{Sistem Operasi Android}

Sistem operasi Android telah mendapatkan popularitas yang luas dalam beberapa tahun terakhir karena sifat lingkungan terbuka dari kerangka kerja Android. Ini telah memberikan fluks luar biasa kepada pengembang Malware untuk menargetkan pengguna Android [16]. Klien ponsel Android adalah media yang on-board

perangkat pemantauan berkomunikasi dengan server cloud. Ia mengumpulkan dan menampilkan data baterai melalui komunikasi Wi-Fi dengan terminal pemantauan terpasang, dan pada saat yang sama mengunggah data ke cloud melalui komunikasi Internet dengan server cloud. Itu dilaksanakan dengan merancang program aplikasi android, yang terutama mencakup desain antarmuka UI, modul komunikasi dan modul database [17].

\section{Metodologi}

Penelitian ini dilakukan pada restoran vegetarian di Kota Batam, Kepulauan Riau. Subjek dan objek penelitian dalam hal ini adalah penjual makanan vegetarian dan pembeli dari makanan vegetarian di Kota Batam. Sedangkan objek penelitian ini adalah aplikasi vege. Persiapan penelitian ini terdiri dari menganalisis persyaratan sistem, memilih ruang lingkup pemrograman, memilih bahasa pemrograman, dan pengujian terhadap aplikasi. Bahasa pemrograman yang digunakan adalah pemrograman java. Pemrograman ini menggunakan (IDE) Android Studio sebagai editor android virtual untuk pengujian aplikasi vege.

Perangkat Keras

Perangkat keras yang digunakan adalah laptop Macbook Air 2017 dan Samsung A51 Smartphone. Tabel 1 menunjukkan spesifikasi Macbook Air 2017, sementara pada Tabel 2 menjelaskan spesifikasi perangkat Smartphone Android:

Tabel 1: Spesifikasi Macbook Air 2017

\begin{tabular}{ll}
\hline Processor & $1,8 \mathrm{GHz}$ Dual-Core Intel Core i5 \\
\hline Graphics & Intel HD Graphics 6000 1536 MB \\
\hline Memory & $8 \mathrm{~GB}$ \\
\hline Display & 13.3 inch \\
\hline
\end{tabular}

Tabel 2: Android Smartphone Samsung A51

\begin{tabular}{ll}
\hline OS & Android 10, One UI 2.1 \\
\hline Chipset & Exynos $9611(10 \mathrm{~nm})$ \\
\hline CPU & Octa-core $(4 \times 2.3 \mathrm{GHz}$ Cortex-A73 \& 4x1.7 GHz Cortex-A53) \\
\hline MEMORY & $6 \mathrm{~GB}$ \\
\hline DISPLAY & Super AMOLED capacitive touchscreen, 16 M colors \\
\hline
\end{tabular}

A. Model Pengembangan

Jurnal KomtekInfo Vol : -- No : --||2019 
Pada bagian ini akan dibahas bagaimana peneliti mengembangkan berdasarkan dari model pengembangan. Proses pengembangan lanjutan dari penelitian ini dapat ditunjukkan pada Gambar 1. Metode pengembangan perangkat lunak dalam model pengembangan terdiri dari 4 jenis kegiatan:

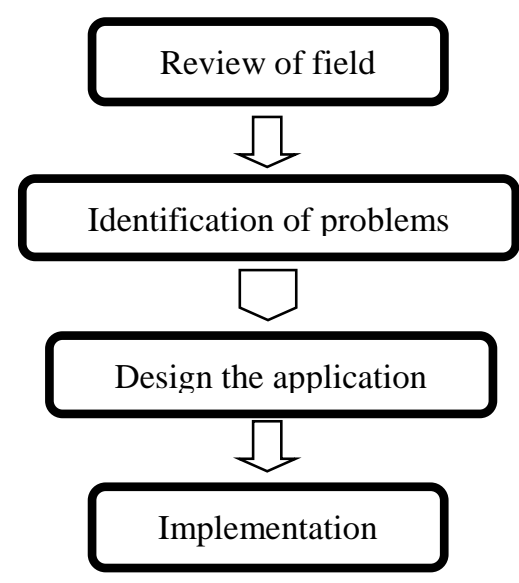

Gambar 1. Development Model

\section{Hasil dan Diskusi}

Pada saat ini aplikasi mobile android mempunyai peran penting dalam perkembangan semua bidang ekonomi baik di Indonesia maupun secara global. Adapun antarmuka dari aplikasi bisa dilihat pada gambar 1 dibawah ini.

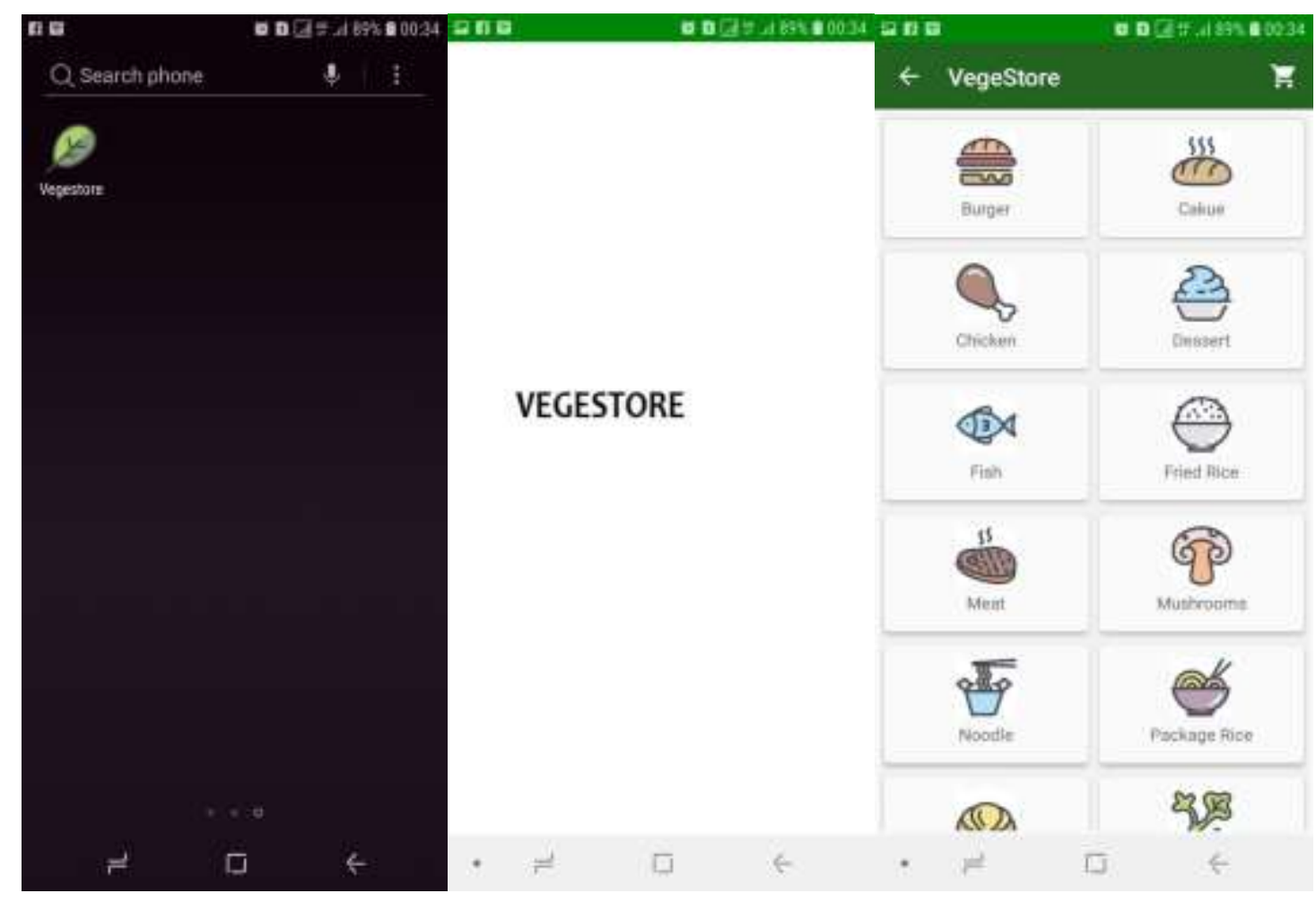

Gambar 1. Halaman Awal Android Aplikasi Vege

Aplikasi Vege mempunyai Icon berbentuk daun yang menandakan bahwa apapun yang dijual didalam aplikasi bersifat vegetarian. Baik itu berbentuk dalam makanan, minuman, ataupun sekalian barang keseharian yang sering dipakai tidak mengandung unsur hewani.

Jurnal KomtekInfo Vol : -- No : --||2019 


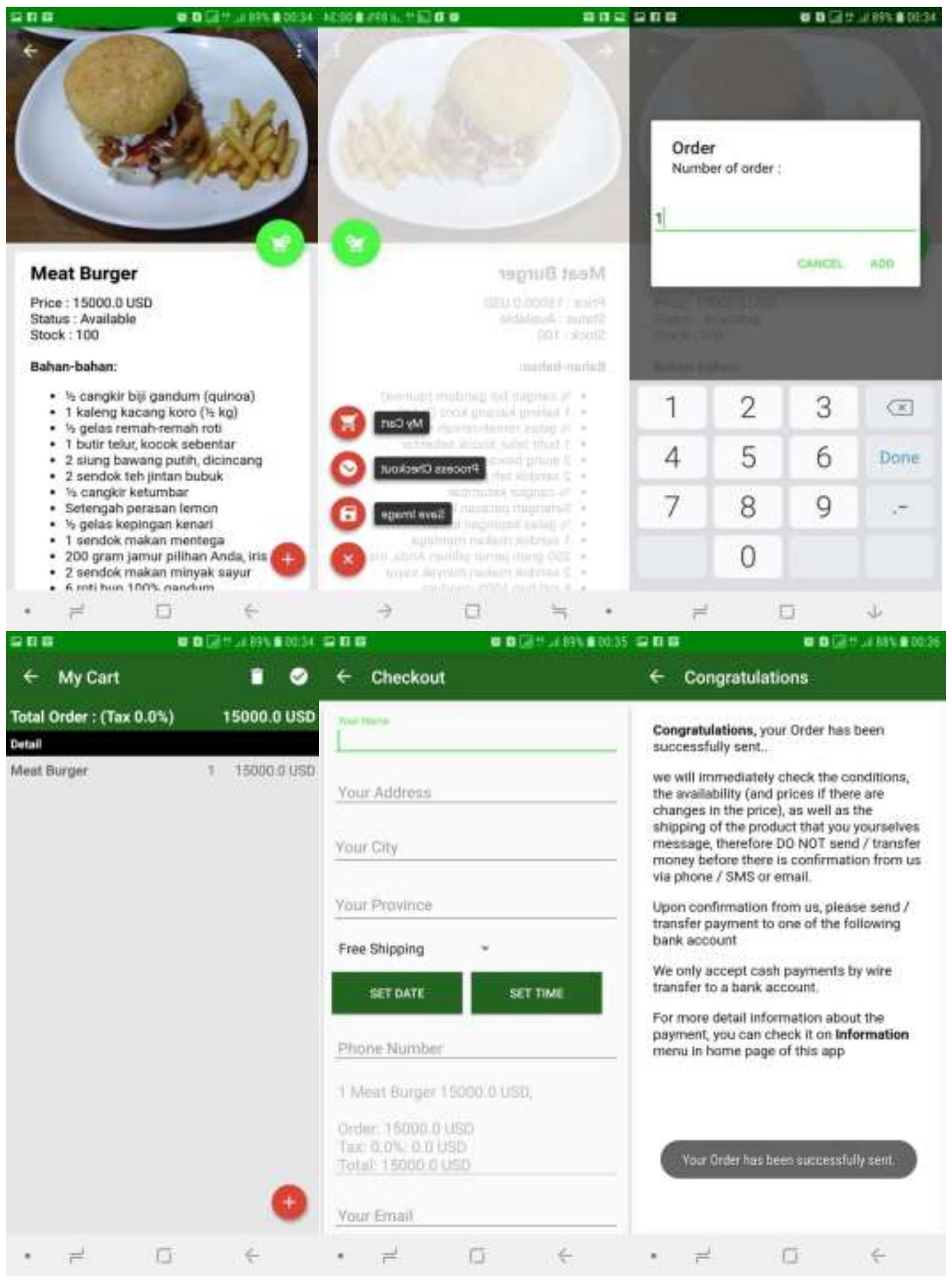

Gambar 2. Proses Pemesanan Makanan Vegetarian

Proses pemesanan makanan pada gambar 2 menunjukan bahwa pemesanan makanan sangatlah mudah. Dari urutan pertama memesan makanan, selanjutnya memilih makanan yang akan dipesan sampai pembayaran makanan melalui uang digital dengan mendapatkan pemberitahuan aplikasi bahwa pemesanan telah selesai dilakukan. Dengan cara ini diharapkan tidak ada sentuhan antar tangan dengan tangan, karena virus covid-19 menyebar dengan cepat melalui uang kertas. 


\section{Kesimpulan}

Berdasarkan hasil analisis penelitian yang dilakukan dalam studi tersebut, dapat ditarik kesimpulan pada poin berikut ini. Pembelian makanan vegetarian dengan menggunakan ponsel android memberikan pengalaman yang mudah bagi masyarakat untuk membantu pemerintah dalam program "dirumah aja". Dengan aplikasi berbasis android juga mampu menjangkau banyak kalangan masyarakat yang mayoritas memiliki ponsel android. Masyarakat tidak perlu keluar rumah untuk membeli makanan.

Ucapan terimakasih atas dukungan dari Universitas Universal Batam dan Kemenristekdikti. Karya ini disponsori oleh "Dana Penelitian Dosen Pemula 2020".

\section{Referensi}

[1] C. Huang et al., "Clinical features of patients infected with 2019 novel coronavirus in Wuhan, China," Lancet, vol. 395, no. 10223, pp. 497-506, 2020, doi: 10.1016/S0140-6736(20)30183-5.

[2] H. Lu, C. W. Stratton, and Y. W. Tang, "Outbreak of pneumonia of unknown etiology in Wuhan, China: The mystery and the miracle," J. Med. Virol., vol. 92, no. 4, pp. 401-402, 2020, doi: 10.1002/jmv.25678.

[3] N. Chen et al., "Epidemiological and clinical characteristics of 99 cases of 2019 novel coronavirus pneumonia in Wuhan, China: a descriptive study," Lancet, vol. 395, no. 10223, pp. 507-513, 2020, doi: 10.1016/S0140-6736(20)30211-7.

[4] Q. Li et al., "Early transmission dynamics in Wuhan, China, of novel coronavirus-infected pneumonia," N. Engl. J. Med., vol. 382, no. 13, pp. 1199-1207, 2020, doi: 10.1056/NEJMoa2001316.

[5] J. T. Wu, K. Leung, and G. M. Leung, "Nowcasting and forecasting the potential domestic and international spread of the 2019-nCoV outbreak originating in Wuhan, China: a modelling study," Lancet, vol. 395, no. 10225, pp. 689-697, 2020, doi: 10.1016/S0140-6736(20)30260-9.

[6] WHO, "Statement on the second meeting of the International Health Regulations (2005) Emergency Committee regarding the outbreak of novel coronavirus (2019-nCoV)." https://www.who.int/news$\mathrm{room} / \mathrm{detail} / 30-01-2020$-statement-on-the-second-meeting-of-the-international-health-regulations(2005)-emergency-committee-regarding-the-outbreak-of-novel-coronavirus-(2019-ncov) (accessed Jul. 15, 2020).

[7] WHO, "WHO Director-General's opening remarks at the media briefing on COVID-19 - 28 February 2020.” https://www.who.int/dg/speeches/detail/who-director-general-s-opening-remarksat-the-media-briefing-on-covid-19---28-february-2020 (accessed Jul. 13, 2020).

[8] E. Seth, "Mobile commerce: A broader perspective," IT Prof., vol. 16, no. 3, pp. 61-65, 2014, doi: 10.1109/MITP.2014.37.

[9] S. Verma and K. Patel, "Association between shopping habit and demographics of M-commerce user's in India using two way ANOVA," 2017 2nd Int. Conf. Converg. Technol. I2CT 2017, vol. 2017-Janua, pp. 38-43, 2017, doi: 10.1109/I2CT.2017.8226090.

[10] K. Said, A. Kurniawan, and O. Anton, "Development of media-based learning using android mobile learning," J. Theor. Appl. Inf. Technol., vol. 96, no. 3, 2018.

[11] A. Bhati, "Bhilwara Model of Containment," no. Icces, pp. 951-956, 2020.

[12] T. Quatieri, T. Talkar, and J. Palmer, "A Framework for Biomarkers of COVID-19 Based on Coordination of Speech-Production Subsystems," IEEE Open J. Eng. Med. Biol., vol. 7014, no. Feb 2014, pp. 1-1, 2020, doi: 10.1109/ojemb.2020.2998051.

[13] Y. Wang, M. Schwartz, and X. Chen, “1 0360-8581,” vol. 3664, no. 860, 2020, doi:

Jurnal KomtekInfo Vol : -- No : --||2019 
10.1109/EMR.2020.3011054.

[14] Andhika, "Vege Application! Using Mobile Application to Promote Vegetarian Food," 2018 Int. Conf. Appl. Eng., pp. 1-6, 2018, [Online]. Available: https://ieeexplore.ieee.org/document/8579152.

[15] C. X. Qi and Z. F. Qi, "Consumer shopping based on mobile computing," 2010 Int. Conf. Comput. Des. Appl. ICCDA 2010, vol. 1, no. Iccda, pp. 189-192, 2010, doi: 10.1109/ICCDA.2010.5541298.

[16] Z. D. Patel, "Malware Detection in Android Operating System," Proc. - IEEE 2018 Int. Conf. Adv. Comput. Commun. Control Networking, ICACCCN 2018, pp. 366-370, 2018, doi: 10.1109/ICACCCN.2018.8748512.

[17] W. Menghua and X. Bing, "A Real-Time Android-Based Monitoring System for the Power LithiumIon Battery Used on EVs," Proc. - 10th Int. Conf. Intell. Comput. Technol. Autom. ICICTA 2017, vol. 2017-October, pp. 245-249, 2017, doi: 10.1109/ICICTA.2017.62. 